\title{
Extremely low genetic diversity and weak population differentiation in the endangered Colombian river turtle Podocnemis lewyana (Testudines: Podocnemididae)
}

\author{
Mario Vargas-Ramírez • Heiko Stuckas • \\ Olga Victoria Castaño-Mora • Uwe Fritz
}

Received: 12 November 2010/ Accepted: 16 August 2011/Published online: 8 September 2011

(C) The Author(s) 2011. This article is published with open access at Springerlink.com

\begin{abstract}
Podocnemis lewyana is an endangered endemic river turtle of Colombia. Using ten unlinked polymorphic microsatellite loci and a 691-bp-long DNA fragment corresponding to the more variable portion of the mitochondrial control region, we investigated genetic diversity and population structure throughout its range. Both neutral markers showed extremely low diversity and weak population differentiation. Our data indicate that the genetic history of $P$. lewyana has been impacted by multiple bottlenecks and population expansion since the Pleistocene. The observed differentiation pattern is most likely the result of historically low genetic variation resulting from restricted geographic range and aggravated by recent anthropogenically induced bottlenecks. Based on slight differences in allele frequencies among populations, we suggest that three regions should be treated as demographically independent Management Units in order to preserve maximal genetic diversity: (1) the Upper Magdalena River Basin, (2) the Lower Magdalena + Lower Cauca + San Jorge River Basins, and (3) the Sinú River
\end{abstract}

Electronic supplementary material The online version of this article (doi:10.1007/s10592-011-0263-4) contains supplementary material, which is available to authorized users.

M. Vargas-Ramírez $(\bowtie) \cdot$ H. Stuckas · U. Fritz

Museum of Zoology (Museum für Tierkunde), Senckenberg Dresden, Königsbrücker Landstr. 159, 01109 Dresden, Germany

e-mail: mario.vargas@senckenberg.de

O. V. Castaño-Mora

Instituto de Ciencias Naturales, Universidad Nacional de

Colombia, Apartado 7495, Bogotá, Colombia
Basin. Among the Management Units, only low to moderate levels of gene flow were detected; these are largely unidirectional from Management Units 1 and 3 into Management Unit 2.

Resumen Podocnemis lewyana es una tortuga endémica y amenazada de Colombia. Usando diez loci polimórficos de microsatélites y un fragmento de 691 pares de bases correspondiente a la porción más variable de la región control mitocondrial, investigamos la diversidad genética y estructura poblacional a través de su rango de distribución. Ambos marcadores neutrales revelaron una diversidad extremadamente baja y débil diferenciación poblacional. Nuestros datos indican que la historia genética de $P$. lewyana ha sido impactada por múltiples cuellos de botella y expansión poblacional desde el Pleistoceno. El patrón de diferenciación observado es más probable el resultado de la variación genética historica baja derivada del rango de distribución restringido, agravada por cuellos de botella recientes resultado de intervención antrópica. Basados en diferencias tenues de frecuencias alélicas entre poblaciones, sugerimos que tres regiones deben ser tratadas como Unidades de Manejo (UM) demográficamente independientes con el fin de preservar al máximo la diversidad genética. (1) Cuenca del alto río Magdalena, (2) Cuencas del bajo río Magdalena + Bajo río Cauca + río San Jorge, y (3) Cuenca del río Sinú. Entre las UM se detectaron niveles bajos a moderados de flujo genético que es principalmente unidireccional de las UM 1 y 3 a la UM 2 .

Keywords Conservation - Genetic diversity Microsatellites - mtDNA - Population structure

Palabras claves Conservación - Diversidad genética . Microsatélites - mtDNA - Estructura poblacional 


\section{Introduction}

The turtle family Podocnemididae, known since the Cretaceous, comprises many extinct and eight extant large freshwater species from South America and Madagascar. Podocnemididae and its sister group, the Afrotropical family Pelomedusidae, are the last survivors of a formerly diverse radiation of turtles, the Pelomedusoides (Gaffney et al. 2006). The genus Podocnemis contains six extant South American species ( $P$. erythrocephala, $P$. expansa, $P$. lewyana, $P$. sextuberculata, $P$. unifilis, $P$. vogli; Fritz and Havaš 2007). P. expansa is listed in the threat category "Lower Risk/Conservation Dependent" by the IUCN Red List of Threatened Species (IUCN 2010); P. erythrocephala, $P$. sextuberculata and $P$. unifilis are treated as "Vulnerable", and P. lewyana is classified as "Endangered". Among the many chelonians under extreme pressure from human exploitation (Klemens 2000), Podocnemis species deserve particular attention as conservation targets because they represent ancient lineages (Vargas-Ramírez et al. 2008; Gaffney et al. 2011).

Podocnemis lewyana is an endangered river turtle, with a distinctly smaller range than most other podocnemidids. It is a medium-sized to large, strictly aquatic species with maximum shell lengths of $32 \mathrm{~cm}$ and $46 \mathrm{~cm}$ in males and females, respectively. The species is confined to the drainage systems of the Sinú, San Jorge, Cauca, and Magdalena Rivers of Colombia (Fig. 1), and the only podocnemidid northwest of the Andes (Páez et al. 2009). As one of the three chelonian species endemic to Colombia (besides P. lewyana: Kinosternon dunni, Mesoclemmys dahli; Fritz and Havaš 2007), the country has a special responsibility to conserve $P$. lewyana. Phylogenetically, $P$. lewyana is sister to the Amazonian blackwater species P. erythrocephala (Vargas-Ramírez et al. 2008).

Populations of P. lewyana are dwindling throughout its distribution range. The Magdalena River Basin is one of the most important Colombian regions in terms of

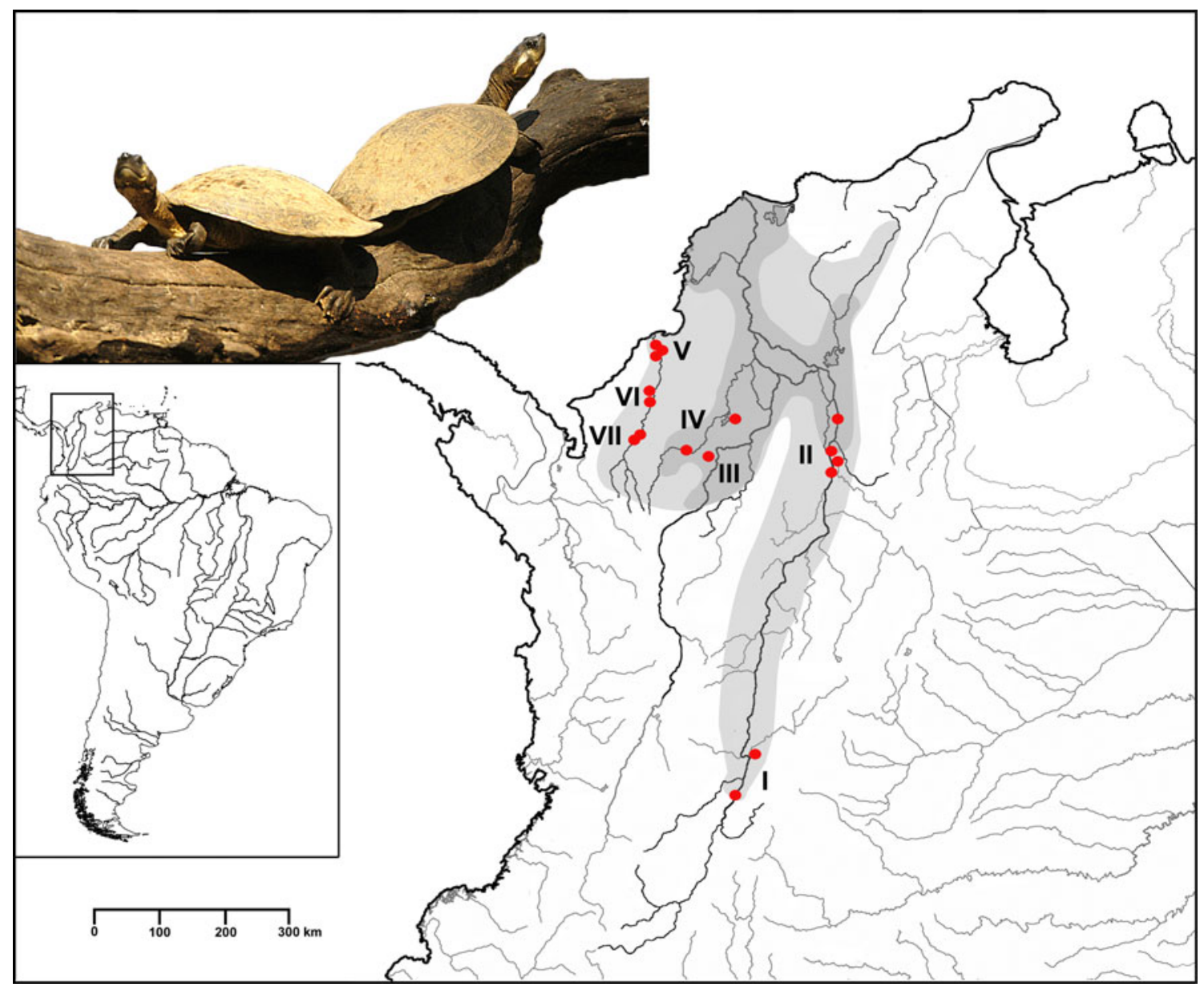

Fig. 1 Distribution of $P$. lewyana in Colombia (light grey) and sampling sites (dots). Roman numerals refer to collecting regions: I: Upper Magdalena, II: Lower Magdalena, III: Man River, Lower
Cauca, IV: San Jorge River, V: Lower Sinú River, VI: Middle Sinú River, VII: Upper Sinú River. Mompos Depression (Depresión Momposina; see "Discussion" section) shown in dark grey 
development and economy. Traditionally, its waters have produced more than $60 \%$ of fish consumed in the country, but fish populations collapsed since the 1970s (Galvis and Mojica 2007). The same factors, habitat destruction and pollution, non-sustainable overexploitation and hydrological changes due to dams, contribute to the decline of P. lewyana (Gallego-García 2004; Vargas-Ramírez et al. 2006, 2007; Gallego-García and Castaño-Mora 2008; Páez et al. 2009). This situation, combined with the species' limited distribution range, makes $P$. lewyana the most threatened of all Podocnemis species.

Little is known about the genetic variation of $P$. lewyana. Vargas-Ramírez et al. (2007) studied a 488-bp-long fragment of the mitochondrial cytochrome $b$ gene in 109 individuals from five regions in the Magdalena and Sinú River Basins and found only two haplotypes, differing by only one substitution. By contrast, in two other Podocnemis species high levels of genetic diversity were discovered with mtDNA and microsatellite data (Pearse et al. 2006; Escalona et al. 2009). In the present study, we use rapidly evolving nuclear and mitochondrial markers [microsatellites, variable part of the control region (CR)] and a range-wide sampling to assess population genetic structure, bottlenecks, gene flow, and population expansion in P. lewyana. We aim at providing a solid foundation for effective management measures under the growing pressure by the increasing human population. The necessary prerequisite for such efforts is knowledge of the population structure that allows the identification of Management Units sensu Moritz (1994), i.e., of populations with significant divergence of allele frequencies at nuclear or mitochondrial loci. P. lewyana lives within a biodiversity hotspot (Myers et al. 2000) and shares its range with a plethora of other taxa, among them a number of endemic fish, amphibian and bird species (Ruiz-Carranza et al. 1996; Acosta-Galvis 2000; Buitrago-Suárez and Burr 2007; Galvis and Mojica 2007; Maldonado-Ocampo et al. 2008; Salaman et al. 2009). Since chelonians are charismatic animals, $P$. lewyana has the potential to become a flagship species for the conservation of its entire ecosystem and all co-distributed species. Our study is embedded in a longlasting conservation and management program for the species supported by the National University of Colombia and an NGO (Biodiversa Colombia).

\section{Materials and methods}

Sampling and laboratory procedures

Between November 2004 and April 2008, blood samples were collected from wild populations in seven regions (four river basins), representing the entire distribution range of $P$. lewyana (Fig. 1; Table 1). The turtles were hand-captured by snorkelling, using traditional fishing nets called "atarrayas", or obtained from local fishermen. Fifty to one-hundred $\mu \mathrm{l}$ of blood were taken from the coccygeal vein of juveniles, and 100-200 $\mu 1$ from that of adults. Blood samples were immediately preserved in plastic vials containing $1 \mathrm{ml}$ of Queen's lysis buffer (Seutin et al. 1991) and stirred until no clots remained. Frozen blood samples are permanently housed in the Instituto de Ciencias Naturales, Universidad Nacional de Colombia, Bogotá;

Table 1 Genetic parameters inferred from microsatellite and CR data for P. lewyana

\begin{tabular}{|c|c|c|c|c|c|c|c|c|c|c|c|c|c|}
\hline \multirow[t]{2}{*}{ Region } & \multirow[t]{2}{*}{ Basin } & \multirow[t]{2}{*}{ Localities } & \multicolumn{7}{|c|}{ Microsatellites (nDNA) } & \multicolumn{4}{|c|}{ Control region (mtDNA) } \\
\hline & & & $N$ & $A_{\mathrm{ob}}$ & $A_{\mathrm{R}}$ & $H_{\mathrm{O}}$ & $H_{\mathrm{E}}$ & $P A$ & PAf & $N$ & $h$ & $\pi$ & Haplotypes \\
\hline I & $\begin{array}{l}\text { Upper } \\
\text { Magdalena }\end{array}$ & Prado, Melgar, Girardot & 49 & 4.20 & 1.93 & 0.271 & 0.261 & 9 & $0.01-0.08$ & 33 & 0.365 & 0.00055 & $\mathrm{~A}, \mathrm{~B}, \mathrm{C}$ \\
\hline II & $\begin{array}{l}\text { Lower } \\
\text { Magdalena }\end{array}$ & $\begin{array}{l}\text { Rio Lebrija, Caño Grande, } \\
\text { Cienaga de Doña Maria }\end{array}$ & 31 & 4.50 & 2.35 & 0.358 & 0.350 & 8 & $0.02-0.03$ & 26 & 0.520 & 0.00098 & $\begin{array}{l}\text { A, D, E, F, } \\
\text { G, H, I }\end{array}$ \\
\hline III & $\begin{array}{l}\text { Lower } \\
\text { Cauca }\end{array}$ & Caucasia & 4 & 2.50 & 2.50 & 0.425 & 0.337 & 2 & 0.12 & 4 & 0.833 & 0.00145 & A, E, J \\
\hline IV & San Jorge & Ayapel, Marralú & 9 & 3.90 & 2.75 & 0.422 & 0.418 & 4 & 0.05 & 6 & 0.333 & 0.00048 & A, J \\
\hline $\mathrm{V}$ & Upper Sinú & Tierra Alta, Valencia & 22 & 2.80 & 1.90 & 0.250 & 0.259 & 2 & $0.04-0.09$ & & & & \\
\hline VI & Middle Sinú & Monteria, Jaraquiel & 13 & 2.70 & 2.10 & 0.300 & 0.300 & 0 & - & 50 & 0.040 & 0.00006 & A, K \\
\hline \multirow[t]{3}{*}{ VII } & Lower Sinú & $\begin{array}{l}\text { Caño Viejo, Cotocá, } \\
\text { Lorica }\end{array}$ & 19 & 3.00 & 2.08 & 0.321 & 0.310 & 1 & 0.05 & & & & \\
\hline & Total & & 147 & - & - & - & - & 26 & & 119 & - & - & - \\
\hline & $\begin{array}{l}\text { Mean/ } \\
\text { overall }\end{array}$ & & - & 6.90 & 2.24 & 0.335 & 0.319 & - & & - & 0.292 & 0.00006 & - \\
\hline
\end{tabular}

Sinú River regions were lumped together for mitochondrial data

$N$ sample size; $A_{\mathrm{ob}}$ mean observed number of alleles per locus; $A_{\mathrm{R}}$ allelic richness; $H_{\mathrm{O}}$ observed heterozygosity; $H_{\mathrm{E}}$ unbiased expected heterozygosity; $P A$ number of private alleles per basin; $P A f$ private alleles frequency range; $h$ haplotype diversity; $\pi$ nucleotide diversity 
subsamples were imported to Germany using the proper CITES permits. Genomic DNA was extracted using a Qiagen DNA blood extraction kit (Qiagen Benelux B.V., Venlo, The Netherlands), following the manufacturer's instructions. Polymerase Chain Reaction (PCR) with fluorescently labelled primers (6-FAM, HEX, PET, NED, Biomers, Ulm, Germany) was used to individually amplify 13 microsatellites originally designed for $P$. unifilis (Fantin et al. 2007) and five additional ones for $P$. expansa (Sites et al. 1999; Valenzuela 2000). Seven markers for $P$. unifilis (Puni1B2, Puni1B10, Puni1B11, Puni1F10, Puni2A9, Puni2C11, Puni2D9, Fantin et al. 2007) and three for P. expansa (Sat62, Sat128, Sites et al. 1999; PE519, Valenzuela 2000) proved to be useful for $P$. lewyana by successful cross-amplification and appropriate levels of polymorphism; the presence of microsatellite repeats was confirmed by sequencing on an ABI 3130xl Genetic Analyzer (Applied Biosystems, Foster City, CA, USA).

Two markers each were combined in duplex PCRs. Thermocycling conditions for the first three duplex PCRs were as follows (primer pairs Sat128 + Puni2C11, Puni1B11 + Puni1F10, Puni1B10 + Puni1B2): Initial denaturing for $1 \mathrm{~min}$ at $94^{\circ} \mathrm{C}, 25$ cycles with denaturing $50 \mathrm{~s}$ at $94^{\circ} \mathrm{C}$, annealing $50 \mathrm{~s}$ at $60^{\circ} \mathrm{C}$, and primer extension for $1 \mathrm{~min}$ at $72^{\circ} \mathrm{C}$, followed by 20 cycles with denaturing $40 \mathrm{~s}$ at $92^{\circ} \mathrm{C}$, annealing $50 \mathrm{~s}$ at $50^{\circ} \mathrm{C}$, and primer extension for $40 \mathrm{~s}$ at $68^{\circ} \mathrm{C}$ and a final elongation of $20 \mathrm{~min}$ at $72^{\circ} \mathrm{C}$. For the primer pairs Puni2A9 + Puni2D9 and Sat62 + PE519, the annealing temperature was $64^{\circ} \mathrm{C}$ in the first set of cycles; the other conditions were the same.

Since Vargas-Ramírez et al. (2007) found virtually no variation in the mitochondrial cytochrome $b$ gene of $P$. lewyana, the more rapidly evolving $\mathrm{CR}$ was chosen as mitochondrial marker. For amplifying and sequencing $691 \mathrm{bp}$ of the more variable portion of the CR, the primer pair LewDLFor1/LewDLRev1 (5'-TAAGTCTAGGAGAGTTT ACGCG-3'/5'-GGTAGATCATCTCCAATTACGG-3') was designed. PCR was performed in a $50 \mu$ volume (PCR buffer, Bioron, Ludwigshafen, Germany, or $50 \mathrm{mM} \mathrm{KCl}$, $1.5 \mathrm{mM} \mathrm{MgCl}$, and $10 \mathrm{mM}$ Tris- $\mathrm{HCl}, 0.5 \%$ Triton X-100, $\mathrm{pH}$ 8.5) containing 1 unit of Taq DNA polymerase (Bioron), 10 pmol dNTPs (Fermentas, St. Leon-Roth, Germany) and 5 or $10 \mathrm{pmol}$ of each primer. Thermocycling conditions were as follows: Initial denaturing for $3 \mathrm{~min}$ at $94^{\circ} \mathrm{C}, 5$ cycles with denaturing $30 \mathrm{~s}$ at $94^{\circ} \mathrm{C}$, annealing $30 \mathrm{~s}$ at $50^{\circ} \mathrm{C}$, and primer extension for $60 \mathrm{~s}$ at $72^{\circ} \mathrm{C}$, followed by 35 cycles with denaturing $30 \mathrm{~s}$ at $94^{\circ} \mathrm{C}$, annealing $30 \mathrm{~s}$ at $48^{\circ} \mathrm{C}$, and primer extension for $60 \mathrm{~s}$ at $72^{\circ} \mathrm{C}$ and a final elongation of $5 \mathrm{~min}$ at $72^{\circ} \mathrm{C}$. PCR products were purified using ExoSAP-IT (USB Corporation, Cleveland, OH, USA) and sequenced directly on both strands on an ABI 3130xl Genetic Analyzer. GenBank accession numbers of the obtained haplotypes are HQ704378-HQ704388.

\section{Data analyses}

Microsatellites

\section{Genetic diversity}

To assess genetic diversity within river basins, HardyWeinberg equilibrium and pairwise linkage disequilibrium were calculated for all loci using the exact test implemented in ARLEQUIN 3.11 (Excoffier et al. 2005). Significance levels were estimated using a Markov chain permutation with 10,000 steps and 1,000 dememorization steps. Observed heterozygosity $\left(H_{\mathrm{O}}\right)$ and Nei's unbiased expected heterozygosity $\left(H_{\mathrm{E}}\right)$ under Hardy-Weinberg equilibrium were also calculated in ARLEQUIN. Allelic richness $\left(A_{\mathrm{R}}\right)$, observed allelic diversity $\left(A_{\mathrm{ob}}\right)$ and the number of alleles per population and locus were calculated using FSTAT 2.9.3.2 (Goudet 2001). GENALEX 6.1 (Peakall and Smouse 2005) was used to reveal the presence and number of private alleles and MICRO-CHECKER 2.2.3 (van Oosterhout et al. 2004) to test for the presence of null alleles. All significance levels for tests involving multiple comparisons were Bonferroni-corrected (Rice 1989).

\section{Population differentiation}

Population structure was inferred with two independent Bayesian clustering methods: (i) a spatially explicit method using exact geographic coordinates as prior information and searching for partitions which are similar with respect to their allele frequencies (BAPS 5.3; Corander et al. 2003) and (ii) a spatially non-explicit method searching for partitions corresponding to populations in Hardy-Weinberg and linkage equilibrium (STRUCTURE 2.3.2, without sampling location information; Pritchard et al. 2000; Hubisz et al. 2009). Their parallel application is advantageous for corroborating the results because the packages employ different computational approaches and BAPS is thought to better identify clusters when $F_{\mathrm{ST}}$ values are small (Latch et al. 2006; François and Durand 2010).

Using STRUCTURE, posterior probabilities were calculated for $K=1$ to $K=n+3$ with $n=7$, corresponding to the number of distinct collection regions. The number of clusters $(K)$ was assessed using an admixture scenario with allele frequencies correlated. The admixture model assumes recent or current gene flow, so that individuals can have ancestors from more than one population. Correlated allele frequencies are expected to occur in populations with common origin. The burn-in was set to $2 \times 10^{4}$ and the number of further MCMC runs to $8 \times 10^{4}$; calculations were repeated 20 times for each $K$. Convergence of likelihood values was reached after the burn-in (values were 
not decreasing or increasing). For estimation of $K$, posterior probabilities [highest $\ln P(D)$ ] and the $\Delta K$ method (Evanno et al. 2005) were used. Barplots were produced to visualize the obtained results for clusters and individual admixture. In BAPS, the number of genetic clusters was estimated by performing five independent runs for different maximum $K$ s (from $K=n$ to $K=n+10$ ), where $n$ was again the number of distinct collection regions (7). Using 500 simulations from posterior allele frequencies, the probability of genetic admixture between each cluster was assessed and individual barplots were obtained.

In order to estimate how much individuals, a priori defined populations and Bayesian clusters contributed to the global genetic variation, a hierarchical AMOVA (Excoffier et al. 1992) as implemented in ARLEQUIN was performed. Pairwise $F_{\mathrm{ST}}$ values were also calculated using ARLEQUIN.

\section{Bottlenecks}

Three methods to detect signatures of population declines were applied, in an attempt to position such population disturbances in a temporal framework. The first method, implemented in BOTTLENECK 1.2.02 tests across all loci for a significant observed heterozygosity excess relative to heterozygosity expected for the number of observed loci (Cornuet and Luikart 1996; Piry et al. 1999). For each sample, the per-locus deviation from expected heterozygosity under a mutation model is calculated by the program, and averaged across all loci. For microsatellites the two-phase mutation model (TPM) was chosen, because it is more suitable for microsatellite data than the strict one-step stepwise mutation model (SMM; Piry et al. 1999). The test parameters were: $95 \%$ single-step mutation, 5\% multiple step mutation, and the variance among multiple steps was set to 12 as suggested by Piry et al. (1999). Statistical significance was determined using a Wilcoxon sign-rank test (Luikart and Cornuet 1998).

The second method, also implemented in BOTTLENECK 1.2.02, evaluates whether the expected distribution of allele frequency classes conformed to expectations of mutation-drift equilibrium. When the rare allele frequency class $(0.00-0.10)$ is less common than other classes, it is likely that the population suffered a bottleneck. This test is qualitative rather than statistical, but is useful in detecting recent bottlenecks (less than a few dozen generations; Luikart et al. 1998).

The third method, the $M$-ratio test (Garza and Williamson 2001), uses a different attribute of the behaviour of microsatellite loci in population bottlenecks. It calculates the test statistic $M=k / r$, where $k$ is the number of alleles and $r$ the overall range in fragment sizes. A declining population will have a smaller $M$-ratio than a stable one because in a small population, $k$ is expected to decrease faster than $r$ due to genetic drift causing the loss of rare alleles. To simulate the expected $M$ values, the program CRITICAL_M (Garza and Williamson 2001) was used. The first test parameters were: $\theta=1$, proportion of onestep mutations $p_{\mathrm{s}}=0.88$, and average size of non-one-step mutation $\Delta_{\mathrm{g}}=2.8$ (as suggested by Garza and Williamson 2001; Kuo and Janzen 2004). To assess the effects of changes in parameter values for the consistency of the results, additional runs were performed using $\theta$ values ranging from 0.1 to $10, p_{\mathrm{s}}$ values ranging from 0.8 to 0.99 , and $\Delta_{\mathrm{g}}$ values ranging from 2.5 to 6 (Kuo and Janzen 2004). The critical value $M_{\mathrm{c}}$, below which bottlenecks are inferred, was determined using the software M-CRIT (Garza and Williamson 2001; http://swfsc.noaa.gov/ textblock.aspx?Division=FED\&id=3298).

The parallel application of all three methods allows exploration of bottleneck effects at a relative timescale (Spear et al. 2006). This concept is based on the fact that the $M$-ratio recovers much more slowly than heterozygosity excess and rare allele distribution (Garza and Williamson 2001). Thus, if a bottleneck signature results from all three methods, a recent or current population decline can be inferred. By contrast, populations showing only a low $M$-ratio, but not significant heterozygosity excess or changes in allelic distribution, most probably underwent a historical decline in size.

\section{Detection of migrants}

In order to assess asymmetrical migration across populations, a Bayesian multilocus genotyping procedure based on Markov chain Monte Carlo (MCMC) methods as implemented in BAYESASS (Wilson and Rannala 2003) was used. In contrast to the classical indirect estimators of gene flow, this method does not require populations to be in Hardy-Weinberg equilibrium. For the first run default settings were used. Subsequent runs incorporated different $\Delta$ values for allele frequency, migration rate, and inbreeding to ensure that proposed changes between chains at the end of the run were between 40 and $60 \%$ of the total chain length (Wilson and Rannala 2003). When the run achieved the acceptable proposed changes, four subsequent runs were performed using different random seed numbers in order to ensure consistency among runs. The values from the four runs were averaged. The program ran for $2 \times 10^{7}$ iterations with the first $10^{6}$ iterations discarded as burn-in. Samples were collected every 2,000 iterations to infer the posterior probability distributions of the migration proportions and individual immigrant ancestries revealed by a population assignment test (Rannala and Mountain 1997). 
Mitochondrial DNA

mtDNA sequences of 119 individuals were generated, containing the more variable portion of the mitochondrial CR. In 28 individuals the CR fragment could not be amplified. Sequences were edited and aligned using CHROMAS 1.51 (http://www.technelysium.com.au/ chromas.html) and BIOEDIT 7.0.5.2 (Hall 1999). Using TCS 1.21 (Clement et al. 2000), all sequences were then collapsed in haplotypes, resulting in 11 haplotypes. Evolutionary relationships among haplotypes were inferred using the statistical parsimony algorithm of TCS. Haplotype diversity $(h)$ and nucleotide sequence diversity $(\pi)$ were calculated in DNASP 5.0 (Librado and Rozas 2009) range-wide and per region to evaluate the genetic signature of possible historical demographic changes. Haplotype frequencies, nucleotide composition, numbers of transitions and transversions, the number of polymorphic sites and the genetic differentiation among sampled river basins and pairwise $F_{\mathrm{ST}}$ values were calculated with ARLEQUIN. Using the population structure revealed by STRUCTURE and BAPS, a hierarchical AMOVA was also performed. Furthermore, to check for population expansion a mismatch distribution test was run in ARLEQUIN and the expansion parameters $\tau, \theta_{1}$ and $\theta_{0}$ were calculated. ARLEQUIN estimates parameters of a sudden demographic (or spatial) expansion using a generalized least-square approach (Schneider and Excoffier 1999). The sum of square deviations (SSD) between the observed data and the data from the simulated expansion model were used as a test statistic; a significant $P$ value rejects the fit of the data to the expansion model (Rosenbaum et al. 2007). Tajima's $D$ and Fu's $F_{\mathrm{S}}$ values were also calculated in ARLEQUIN; significantly negative $D$ and $F_{\mathrm{S}}$ values suggest historical population growth (Tajima 1989; Fu 1997). Pairwise mismatch distribution graphs were produced in DNASP 5.0. These methods are expected to either identify past demographic events such as population expansion or to detect when demographic historical information has disappeared due to the influence of recent population bottlenecks (Weber et al. 2004; Johnson et al. 2007).

\section{Isolation-by-distance}

To assess the possible influence of isolation-by-distance (IBD) patterns on population structuring, Mantel tests as implemented by IBD (Bohonak 2002) were used for microsatellite and mitochondrial data. Pairwise population values of $F_{\mathrm{ST}} /\left(1-F_{\mathrm{ST}}\right)$ were compared against geographical distances corresponding to the shortest river route between each pair of populations (Fetzner and Crandall 2003).

\section{Results}

Microsatellites

\section{Genetic diversity}

None of the studied loci differed significantly from HardyWeinberg expectations. In addition, no significant linkage disequilibrium between any pair of loci was detected; neither for any river basin nor across basins after Bonferroni correction. Subsequently, microsatellite data were used to analyze diversity in all seven collecting regions (Table 1). The number of alleles for each locus ranged from two (Puni1B2, Puni1B10, Puni2A9) to 21 (PE519); Puni2D9 showed 12 alleles and the others less than 10 alleles (Table S1). From a total of 69 alleles, 26 private ones were found at low frequency. The highest number of private alleles was found in the Upper Magdalena and Lower Magdalena (Table 1). Allelic richness $\left(A_{\mathrm{R}}\right)$ per population ranged from 1.90 to 2.75 (mean: 2.24) and the observed allelic diversity $\left(A_{\mathrm{ob}}\right)$ was slightly higher (2.50-4.50; overall: 6.90; Table 1). Expected heterozygosity was low across river basins and ranged from 0.259 to 0.418 (mean: 0.319); the lowest value was observed in Upper Sinú and the highest in San Jorge. Null alleles were not detected.

\section{Population differentiation}

To reveal population structuring among the 147 turtles, two different Bayesian algorithms were used as implemented in the software packages STRUCTURE (searching for genetic populations in Hardy-Weinberg and linkage equilibrium) and BAPS (searching for genetic populations showing characteristic allele frequencies). Their parallel application is advisable because they employ different algorithms and BAPS is thought to better identify clusters when $F_{\mathrm{ST}}$ values are small (Latch et al. 2006; François and Durand 2010), which is the case in our data set (Table S2).

STRUCTURE found three distinct units $(K=3$, revealed by the highest mean posterior probability and $\Delta K$ method; Table S3). One cluster corresponded to the Upper Magdalena (I); another one to the Lower Magdalena (II) + Lower Cauca (III) + San Jorge (IV); and the third one to the Sinú River $(\mathrm{V}+\mathrm{VI}+\mathrm{VII})$. This structuring was independently confirmed by BAPS $(K=3$; confidence of $P=99 \%$ ). These units, especially cluster 2 , showed a high degree of admixture (Fig. 2).

A hierarchical AMOVA revealed that $7.18 \%$ of the total variation occurred among these three major Bayesian clusters $\left(F_{\mathrm{CT}}=0.0718 ; P=0.00001\right)$. Among the a priori defined populations within these clusters only $1.12 \%$ occurred $\left(F_{\mathrm{SC}}=0.01203 ; P=0.102\right)$. The vast majority 
Table 2 Results of the tests for past bottlenecks in P. lewyana

\begin{tabular}{llllc}
\hline Site & $\begin{array}{l}\text { Heterozygosity } \\
\text { excess }\end{array}$ & Allele frequency & \multicolumn{2}{c}{$M$-ratio test } \\
\cline { 3 - 4 } & & & $M_{\text {c }}$ & $0.80(10)$ \\
Lower Magdalena & $0.0005^{*}$ & - & $0.76(7)$ & 0.59 \\
Lower Cauca & $0.05^{*}$ & - & $0.78(10)$ & 0.42 \\
San Jorge & $0.001^{*}$ & - & $0.80(8)$ & $0.89(10)$ \\
Upper Sinú & $0.04^{*}$ & - & $0.80(9)$ & 0.48 \\
Middle Sinú & $0.0001^{*}$ & - & $0.81(9)$ & 0.58 \\
Lower Sinú & $0.005^{*}$ & - & $0.81(10)$ \\
Cluster 1 (Upper Magdalena) & 0.055 & Normal & 0.44 \\
Cluster 2 (Lower Magdalena, & $0.0005^{*}$ & Shifted & 0.47 \\
$\quad$ Lower Cauca, San Jorge) & $0.0068^{*}$ & Shifted & $0.81(10)$
\end{tabular}

Heterozygosity excess values bearing an asterisk are statistically significant. In the $M$-ratio test, values below $M_{\mathrm{c}}$ indicate bottlenecks. In brackets, number of loci contributing to the $M$-ratio test

of the total genetic variation $(91.7 \%)$ was found within a priori defined populations, i.e., on the individual level $\left(F_{\mathrm{ST}}=0.08199 ; P=0.002\right)$. However, Mantel tests of an IBD analysis revealed no correlation between genetic divergence (pairwise $F_{\mathrm{ST}}$ ) and geographic distances ( $Z=2.53, r=0.31, P=0.256)$, so that it can be concluded that, despite the weak differentiation, the observed divergence is not due to IBD but to population differentiation.

\section{Bottlenecks}

Evidence for bottlenecks was detected for all seven collecting regions and for all three clusters suggested by STRUCTURE and BAPS (Table 2). The test for heterozygosity excess was non-significant only for the Upper
Magdalena River, although the value of 0.055 was very close to the significance limit (the Upper Magdalena River corresponds to the distinct cluster 1 of STRUCTURE and BAPS). The allele frequency test was run only for the three population clusters of STRUCTURE and BAPS, because it cannot be reliably applied to sample sizes below 30 individuals (Cornuet and Luikart 1996). A modal shift in allele frequency classes as expected from a recent bottleneck was found for the clusters 2 and 3, but not for cluster 1 (Upper Magdalena). For all runs of the $M$-ratio test using different parameters, consistent results were obtained. The $M$-ratios were below the $M_{\mathrm{c}}$ thresholds for all sampling regions and all population clusters, indicating bottlenecks.

A direct comparison of the results of all three bottleneck analyses provides evidence for an old bottleneck in the Upper Magdalena River that predates the events observed

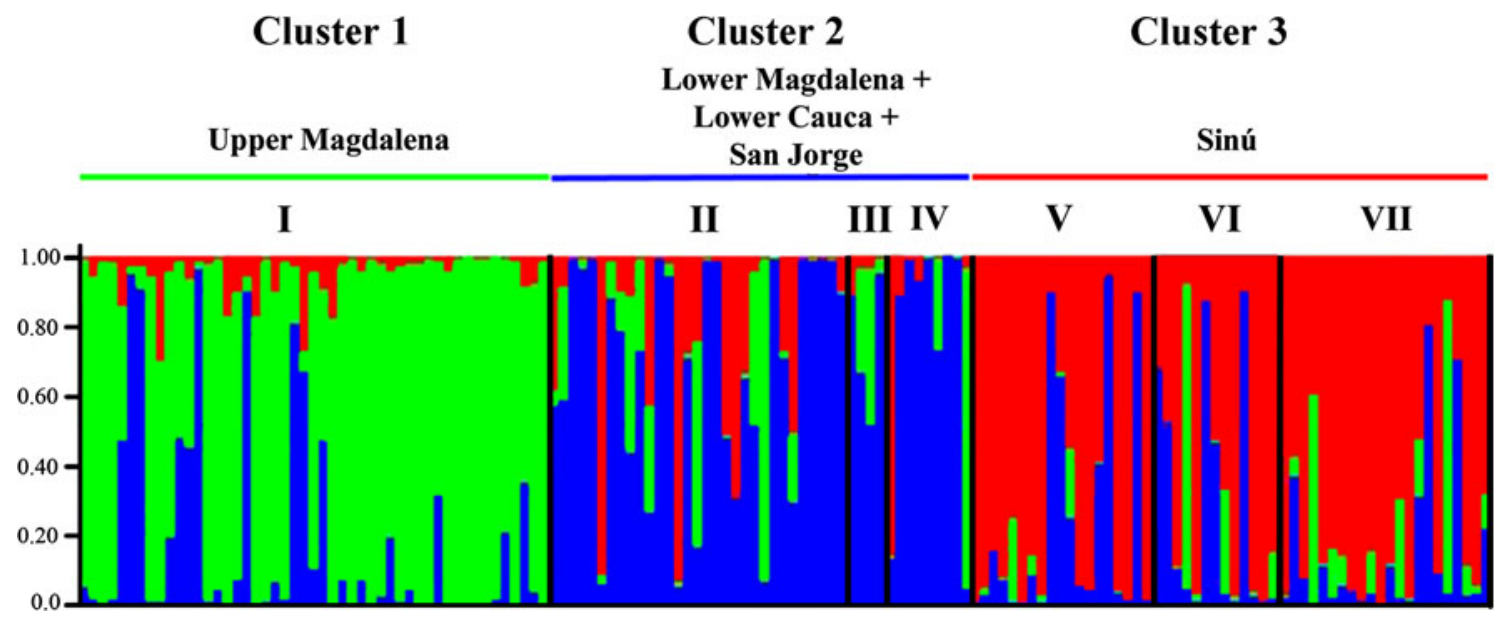

Fig. 2 Barplots from STRUCTURE suggesting three suggesting three clusters $(K=3)$ based on 10 unlinked polymorphic microsatellite loci (shown is the run with the highest mean posterior probability) 
Table 3 Gene flow estimate for each cluster pair in a metapopulation of P. lewyana

\begin{tabular}{ll}
\hline Cluster pair & Gene flow $(m)$ \\
\hline $1-2$ & $0.099(0.014-0.204)$ \\
$2-1$ & $0.008(0-0.035)$ \\
$1-3$ & $0.007(0-0.030)$ \\
$3-1$ & $0.017(0.000-0.064)$ \\
$2-3$ & $0.008(0-0.040)$ \\
$3-2$ & $0.172(0.071-0.275)$ \\
\hline
\end{tabular}

Estimates of gene flow represent the mean migration rate and 95\% confidence interval (in brackets) for a pair of clusters (subpopulations)

in all other a priori defined populations and Bayesian clusters. This conclusion is derived from the low $M$-ratio in combination with the non-significant test for heterozygosity excess and the normal allelic distribution in the Upper Magdalena.

\section{Detection of migrants}

When the BAYESASS analyses of migration were run with the seven a priori defined populations corresponding to the collecting regions, inconsistencies were detected between different runs among populations with no (or extremely low) differentiation. It has been suggested that the estimates of short-term migration rates and individual migrant ancestries may have a low accuracy for weakly differentiated populations (Wilson and Rannala 2003). Therefore, we present here only the estimates for the three units identified by STRUCTURE and BAPS. Using these clusters, consistent results were obtained (Table 3) that suggested asymmetric migration, with a much stronger influx from cluster 1 (Upper Magdalena) to cluster 2 (Lower Magdalena + Lower Cauca + San Jorge) than vice versa (Fig. 3). A similar situation occurred with respect to clusters 2 and 3 (Sinú). In this case a much stronger immigration was suggested from cluster 3 to cluster 2 than in the opposite direction (Fig. 3). For cluster 1, total emigration was estimated as 0.157 , total immigration 0.025 , and net emigration 0.132. For cluster 2, total emigration was 0.016, total immigration 0.271 , and net emigration -0.0254 . For cluster 3 , total emigration was 0.189 , total immigration 0.014 , and net emigration 0.175 . To enable an easy evaluation of data quality for migration rates, the $95 \%$ confidence intervals are reported along with the means for these values (Table 3), as suggested by Wilson and Rannala (2003).

The relatively isolated status of the Upper Magdalena (cluster 1) and Sinú (cluster 3) was also suggested by population assignment tests using BAYESASS (Table S4). The majority of turtles of these two clusters were identified as residents (no migrants) and only low percentages as migrants or migrant's offspring. In contrast, only $16.32 \%$ of the individuals of cluster 2 were identified as residents and $28.01 \%$ as

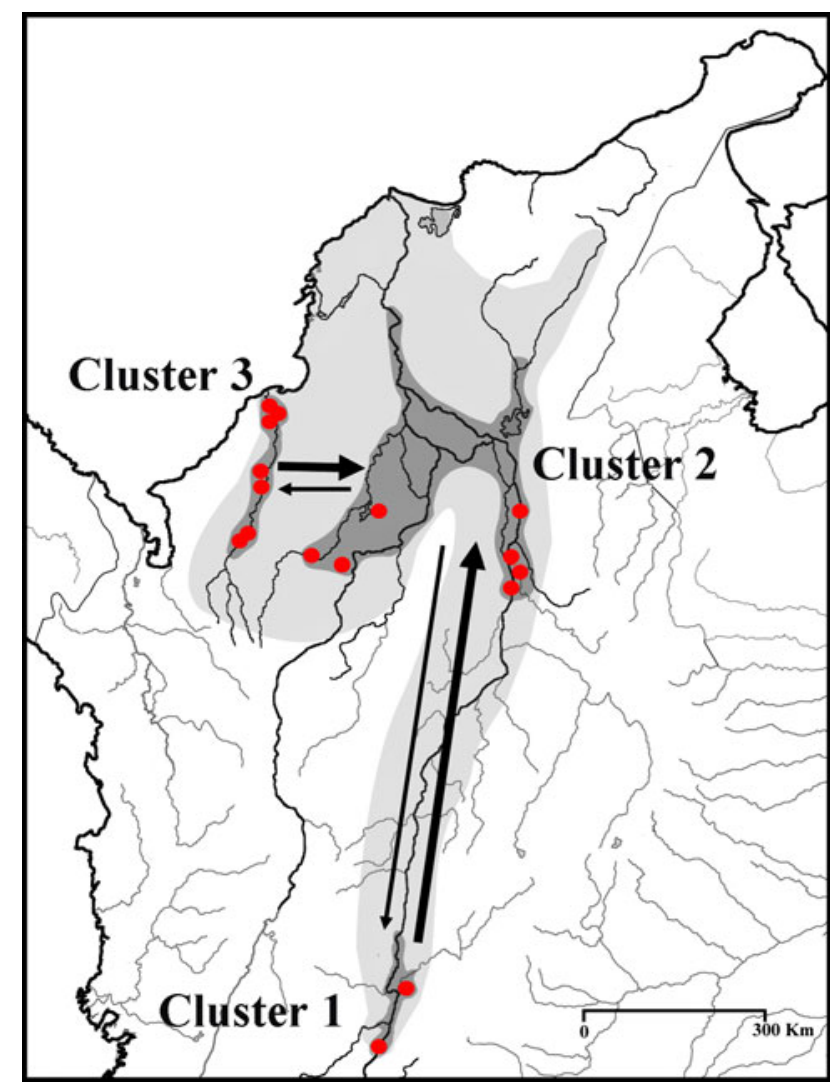

Fig. 3 Gene flow pattern among populations of P. lewyana. Arrows indicate direction of gene flow from Cluster 1 (Upper Magdalena River) and Cluster 3 (Sinú River Basin) into Cluster 2 (Lower Magdalena + San Jorge + Lower Cauca Rivers). Relative amount of directional gene flow is represented by the thickness of each arrow

migrants from the other two clusters and $55.67 \%$ as migrant's offspring, matching the high amount of admixture for this cluster as suggested by STRUCTURE (see above).

\section{Mitochondrial DNA}

Based on the comparison of a 691-bp-long fragment of the mitochondrial CR of 119 P. lewyana, 11 distinct haplotypes were identified (Table S5), differing in 11 polymorphic sites (nine transitions and two transversions; Table S6). The most frequent haplotype A was found in all populations. In three regions (Upper Magdalena, Lower Magdalena, Sinú) private haplotypes occurred (Tables 1, S5). The haplotype network showed a star-like structure (Fig. S1) and most of the haplotypes were distinct from the most frequent and ancestral haplotype A by one mutational step; the only exception was haplotype $\mathrm{H}$, which differed by two mutational steps. The overall haplotype diversity $(h)$ was 0.292 and nucleotide diversity $(\pi)$ was 0.00006 . Individual values for each of the seven study regions are summarized in Table 1.

In order to explore demographic events, Tajima's $D$ and Fu's $F_{\mathrm{S}}$ values were computed and mismatch distribution 
Table 4 Comparison of genetic parameters inferred from microsatellite and CR data of $P$. lewyana (bold) and other continental chelonian species

\begin{tabular}{|c|c|c|c|c|c|c|c|c|c|c|c|}
\hline \multirow[t]{3}{*}{ Taxon } & \multirow[t]{3}{*}{ Region } & \multicolumn{9}{|c|}{ Marker } & \multirow[t]{3}{*}{ Source } \\
\hline & & \multicolumn{5}{|c|}{ Microsatellite nDNA } & \multicolumn{4}{|c|}{ mtDNA } & \\
\hline & & $N$ & Loci & $H_{\mathrm{O}}$ & $H_{\mathrm{E}}$ & $A_{\mathrm{R}}$ & $N$ & Fragment & $h$ & $\pi$ & \\
\hline Astrochelys radiata & Madagascar & 323 & 13 & 0.76 & 0.80 & 8.90 & - & - & - & - & $\begin{array}{l}\text { Rioux Paquette } \\
\text { et al. (2009) }\end{array}$ \\
\hline Emydoidea blandingii & Nova Scotia, Canada & 129 & 5 & 0.55 & 0.55 & 8.00 & - & - & - & - & $\begin{array}{l}\text { Mockford et al. } \\
\text { (2005) }\end{array}$ \\
\hline Emys orbicularis & $\begin{array}{l}\text { Western, central and } \\
\text { southern Europe }\end{array}$ & 382 & 8 & 0.63 & 0.72 & 5.15 & - & - & - & - & Pedall et al. (2011) \\
\hline Emys trinacris & Sicily, Italy & 31 & 8 & 0.55 & 0.68 & 4.86 & - & - & - & - & Pedall et al. (2011) \\
\hline Gopherus berlandieri & Texas, USA & 138 & 8 & 0.47 & 0.52 & 5.21 & - & - & - & - & $\begin{array}{l}\text { Fujii and Forstner } \\
\text { (2010) }\end{array}$ \\
\hline $\begin{array}{l}\text { Graptemys } \\
\text { geographica }\end{array}$ & Ontario, Canada & 109 & 5 & 0.65 & 0.63 & 4.15 & - & - & - & - & $\begin{array}{l}\text { Bennett et al. } \\
\text { (2010) }\end{array}$ \\
\hline Malaclemys terrapin & $\begin{array}{l}\text { Gulf and Atlantic coasts, } \\
\text { USA }\end{array}$ & 320 & 6 & 0.76 & 0.79 & 7.44 & - & - & - & - & $\begin{array}{l}\text { Hauswaldt and } \\
\text { Glenn (2005) }\end{array}$ \\
\hline Podocnemis unifilis & $\begin{array}{l}\text { Amazon and Orinoco } \\
\text { Basins }\end{array}$ & 312 & 5 & 0.69 & 0.70 & 7.25 & - & - & - & - & $\begin{array}{l}\text { Escalona et al. } \\
\text { (2009) }\end{array}$ \\
\hline Terrapene ornata & Illinois, Nebraska, USA & 74 & 11 & 0.57 & 0.72 & 9.27 & - & - & - & - & $\begin{array}{l}\text { Kuo and Janzen } \\
(2004)\end{array}$ \\
\hline $\begin{array}{l}\text { Chelonoidis nigra } \\
\text { vandenburghi }\end{array}$ & $\begin{array}{l}\text { Galápagos Islands, } \\
\text { Ecuador }\end{array}$ & 162 & 10 & 0.60 & 0.68 & 8.7 & 135 & $\mathrm{CR}$ & 0.52 & 0.0044 & $\begin{array}{l}\text { Beheregaray et al. } \\
\text { (2003) }\end{array}$ \\
\hline Emys orbicularis & Spain & 261 & 7 & 0.72 & 0.71 & 5.27 & 261 & $\mathrm{CR}, \mathrm{ND} 4$ & 0.81 & 0.00187 & $\begin{array}{l}\text { Velo-Antón et al. } \\
\text { (2008) }\end{array}$ \\
\hline $\begin{array}{r}\text { Macrochelys } \\
\text { temminckii }\end{array}$ & Mississippi River, USA & 195 & 7 & 0.36 & 0.37 & 2.38 & 195 & $\begin{array}{l}\text { CR, } \\
\text { tRNA- } \\
\text { Pro }\end{array}$ & 0.50 & 0.001 & $\begin{array}{l}\text { Echelle et al. } \\
\text { (2010) }\end{array}$ \\
\hline Podocnemis expansa & $\begin{array}{l}\text { Amazon and Orinoco } \\
\text { Basins }\end{array}$ & 453 & 9 & - & 0.75 & 6.4 & 293 & $\mathrm{CR}$ & 0.65 & 0.00256 & Pearse et al. (2006) \\
\hline Podocnemis lewyana & Colombia & 147 & 10 & $\mathbf{0 . 3 3}$ & 0.32 & 2.24 & 119 & CR & 0.29 & 0.00006 & This study \\
\hline
\end{tabular}

$N$ sample size; $H_{\mathrm{O}}$ observed heterozygosity; $H_{\mathrm{E}}$ unbiased expected heterozygosity; $A_{\mathrm{R}}$ allelic richness; $h$ haplotype diversity; $\pi$ nucleotide diversity

analyses performed (i) for all regions as given in Table 1, except that localities at the Sinú River were grouped together, and (ii) for all river basins lumped together (Table S7). The distribution of pairwise nucleotide differences was consistent with expectations of a unimodal distribution indicating population expansion (Fig. S2; Table S7). The Tajima's $D$, and Fu's $F_{\mathrm{S}}$ values were negative, and in the Lower Magdalena, Sinú, and all regions lumped together $D$ and $F_{\mathrm{S}}$ were statistically significantly different from zero, again suggesting population expansion.

According to a hierarchical AMOVA, $7.05 \%$ of the total variation occurred among the three major Bayesian clusters $\left(F_{\mathrm{CT}}=0.07059 ; P=0.01\right)$, and only $0.43 \%$ of the total variation was found among populations within these clusters $\left(F_{\mathrm{SC}}=0.00429 ; P=0.4511\right)$. The majority of global genetic variation $(92.52 \%)$ was found on the individual level within the a priori defined populations $\left(F_{\mathrm{ST}}=0.07458 ; P=0.007\right)$. Since the Mantel tests revealed no correlation between genetic and geographic distances $(Z=281.03, r=0.34, P=0.184)$, the observed genetic structure cannot be interpreted as the result of IBD and it has to be concluded that it reflects weak, but discernable population differentiation.

\section{Discussion}

Population structure in the face of low genetic variability and gene flow

The levels of heterozygosity, allelic richness, and haplotype and nucleotide diversities indicate that $P$. lewyana is a species with extremely low genetic diversity. This is underlined by a comparison with other chelonian species (Table 4). The distinctly lower values of $P$. lewyana strongly contrast with most of the other species, some of which are or were heavily exploited and experienced sharp 
population declines (Astrochelys radiata, Chelonoidis nigra, Macrochelys temminckii, P. expansa, P. unifilis).

Despite this low diversity, the two Bayesian clustering algorithms independently unravelled evidence for three distinct genetic clusters within P. lewyana, corresponding to (1) The Upper Magdalena River Basin, (2) the Lower Magdalena + Lower Cauca + San Jorge River Basins, and (3) the Sinú River Basin. Yet, the hierarchical AMOVAs (for microsatellites and mtDNA) indicate that most of the global variation (approx. 92\% for both markers) occurs on the individual level, but that some $7 \%$ of the variation corresponds to differences among the three clusters. Thus, our data provide evidence for a discernable, albeit weak population structure in $P$. lewyana.

Along the Magdalena River, P. lewyana is rare and the species has apparently experienced marked declines in most sites where it still exists (Restrepo et al. 2008). Although several intermediate localities between the Upper and Lower Magdalena River were visited during the course of our investigation (where the species is known to occur), the few turtles observed were spotted only in wide and deep parts of the river, where it was not possible to catch them. Even baited funnel traps were unsuccessful, suggesting the species is very rare there. The genetic characterization of intermediate populations which connect cluster 1 with cluster 2 must remain therefore pending, and we cannot exclude the possibility that part of the observed population differentiation corresponds to anthropogenically induced subdivision by local extirpation.

\section{Historical demography}

Our analyses indicate that the genetic history of $P$. lewyana has been influenced by multiple bottlenecks throughout the distribution range. The results of the $M$-ratio test in combination with the analyses of heterozygosity excess and allele frequency shifts suggest an old bottleneck in the Upper Magdalena region. The same analyses indicate, however, at least one secondary, younger decline in genetic diversity in the other areas of the distribution range. Indeed, the signal for the $M$-ratio test can persist for hundreds of generations, depending on the rate of mutation and population turnover (Garza and Williamson 2001). P. lewyana as a large-sized turtle has a long life-expectancy, which suggests together with the low mutation rate in turtles (Avise et al. 1992; FitzSimmons 1998) that the signal for a past bottleneck may be preserved for a very long time.

Like the northern hemisphere, South America has been severely impacted by Pleistocene glaciations (Clapperton 1993). The effects of the Last Glacial Maximum (LGM) on the hydrological and habitat conditions in the Magdalena River Basin, previously influenced by the rain shadow of the uplift of the western Cordillera and Serranía of Perijá, were surely considerable, corresponding to a marked reduction in the amount of water present in the drainage (Galvis et al. 1997), and resulting in pronounced changes of the aquatic and terrestrial ecosystems. Furthermore, in the Holocene at least four additional dry periods (5000, 2000, 700, and 500 years ago) have affected the Magdalena River Basin (Livingstone and van der Hammen 1978; Archila-M. 1993). It seems reasonable to suppose that such historical events acted in concert with subsequent human impact. The old bottleneck in the Upper Magdalena could result from Pleistocene reductions in population size while younger events, including anthropogenic pressure, are likely to be reflected by the evidence for the more recent decline.

Large parts of the distribution range of $P$. lewyana were transformed by pre-Hispanic cultures, suggesting that anthropogenic impact can last for centuries. The Mompos Depression, today with low human population density, was densely inhabited in pre-Hispanic times. The Zenú and their ancestors built a large and complex network of canals extending over more than 500,000 hectares of swamp (Plazas et al. 2005), and there is archaeological evidence for the species' utilization by indigenous peoples (Puerto Hormiga: from 5,000 to 4,500 years ago, Mompos Depression: 2,500-750 years ago, Valle de Santiago: 1,600-1,000 years ago; Archila-M. 1993). This suggests that the extreme level of exploitation of turtle meat and eggs as known today (Vargas-Ramírez et al. 2006) may have occurred for many centuries, and a similar scenario recently has been proposed for a Central American river turtle (Dermatemys mawii; González-Porter et al. 2011). Such intensive historical harvesting, along with the current exploitation and habitat destruction, may have caused the genetic signal for recent population decline. In any case, the small distribution range of $P$. lewyana surely has contributed to the observed low diversity.

Compared to the other study regions, genetic differentiation is most pronounced in the Upper Magdalena River. Among others, two private mitochondrial haplotypes (one of them identified in six individuals) occur there and the highest number of private alleles. This suggests that the Upper Magdalena may have harboured a population of $P$. lewyana that was isolated during past dry periods.

Much of the distribution range of $P$. lewyana corresponds to the Mompos Depression (Depresión Momposina, Fig. 1), the largest swamp region of Colombia with $24,650 \mathrm{~km}^{2}$ (Anonymus 2002). It is located between the Caribbean lowland and the Serranías of Ayapel, San Lucas and Perijá. This interior delta, where the waters from the Magdalena, César, San Jorge and Cauca Rivers converge, experiences periodic inundations and remains flooded from April until November (Plazas et al. 2005). Its abundance of water suggests that the Mompos Depression served as an important refuge during past dry periods, whereas the 
relatively high degree of admixture argues also for a role as genetic hub for the distinct populations.

However, our data indicate that, apart from bottleneck events, population expansion is also likely to have shaped the current population structure. Evidence for population expansion is mainly provided by the unimodal distribution of pairwise differences between mtDNA haplotypes (mismatch distribution; Fig. S2). By contrast, bottlenecks are expected to show multimodality in mismatch distributions (Rogers and Harpending 1992; Weber et al. 2004; Johnson et al. 2007). Thus, the results of the mismatch distribution analysis suggest a signature of population expansion, and this is further supported by our observation of negative Tajima's $D$ and Fu's $F_{\mathrm{S}}$ values and the star-like haplotype network topology (Fig. S1; Table S7). We interpret this finding as evidence for a recovery of individual numbers after historical bottlenecks.

\section{Conservation implications}

Our study revealed for $P$. lewyana a clear population structure, but overall very low levels of genetic diversity and allelic richness. This has key implications for conservation. The present decline of $P$. lewyana throughout its distribution range is known to be caused by overexploitation and habitat destruction (Vargas-Ramírez et al. 2006; Gallego-García and Castaño-Mora 2008; Restrepo et al. 2008; Páez et al. 2009). This will certainly aggravate the low genetic diversity, so that strategies are needed to counteract further loss of diversity. The population structure of $P$. lewyana implies that conservation efforts cannot focus only on one part of the distribution range. For preserving the present genetic diversity, at least three independent Management Units (Moritz 1994) need to be considered, i.e., (1) the Upper Magdalena River Basin, (2) the Lower Magdalena + Lower Cauca + San Jorge River Basins, and (3) the Sinú River Basin.

Reserves should be established in each of these three regions and in the region between the Upper and Lower Magdalena River sections because it corresponds to an important gateway for genetic exchange. In general, migration routes along the river corridors and temporal body waters that connect river basins need to be maintained for ensuring gene flow (e.g., seasonal water connections between the Sinú River Basin and Mompos Depression populations).

Of outstanding importance in this context is to accept the challenge and responsibility of assuring the long-term survival of $P$. lewyana. We encourage the Colombian government through the Environmental Ministry to promote a dialogue among stakeholders (research institutes, regional environmental corporations, governmental and non-governmental organizations, zoos, land owners, human communities, etc.) to collaborate on efforts for in-situ and ex-situ preservation of the species. In order to effectively reduce the consumption of eggs and adults, or at least to achieve a sustainable use, community-based local education programs need to be implemented. Previous efforts were successful on a local scale (Vargas-Ramírez et al. 2006, 2009; for the Upper Magdalena River: Vargas-Ramírez 2007; for the Sinú River: Gallego-García 2006). Now it is time to learn from these experiences and to expand them over all distribution regions. The future of $P$. lewyana, and of all of its many co-distributed species, is in our hands.

Acknowledgments We thank the Grupo de Conservación y Biodiversidad of the Instituto de Ciencias Naturales de la Universidad Nacional de Colombia (director: Jésus Orlando Rangel-Churio), the Fundación Biodiversa Colombia, the Instituto de Biología Tropical Roberto Franco (IBTRF) de la Universidad Nacional de Colombia (director: María Cristina Ardíla-Robayo), and Willington Ortiz for institutional and logistical support. This study was made possible by the 'Contrato de acceso a recursos genéticos para investigación científica sin interés comercial No. 02' signed between the Ministerio de Ambiente, Vivienda y Desarrollo Territorial de Colombia and Mario Vargas-Ramírez. For collection of samples we are grateful to Diana Sarmiento (Piscilago Zoo), Felipe Lozano, Jimena Prieto, Juan Manuel Vargas (Upper Magdalena River), Wilsón Perez from Corpocesar (Lower Magdalena River), Gladys Cardenas and Natalia Gallego (Sinú and San Jorge Rivers). For invaluable support in obtaining the permits we are indebted to Aleyda Martinez and Matílde Cardona from the Ministerio de Ambiente, Vivienda y Desarrollo Territorial de Colombia. We further thank Rubén Darío Castañeda and the ecological group of the school Luis Felipe Pinto in Prado, Tolima, Nicolás Vargas, Germán Vargas, Ana Maria Ramírez and the visited communities along the Sinú, Magdalena, San Jorge, and Cauca Rivers for their hospitality and support. Thanks for help with laboratory work go to Anke Müller, Anna Hundsdörfer, and Christian Kehlmaier (Museum of Zoology, Senckenberg Dresden). Thanks go also to Miguel Vences and Susanne Hauswaldt (Department of Evolutionary Biology, TU Braunschweig) for important suggestions and the Turtle Conservation Fund (TCF) for financial support for field work. Mario Vargas-Ramírez and laboratory work were funded by a fellowship of the German Academic Exchange Service (DAAD) and by the Deutsche Forschungsgemeinschaft (DFG, FR 1435/5-1).

Open Access This article is distributed under the terms of the Creative Commons Attribution Noncommercial License which permits any noncommercial use, distribution, and reproduction in any medium, provided the original author(s) and source are credited.

\section{References}

Acosta-Galvis AR (2000) Ranas, salamandras y cecilias (Tetrapoda: Amphibia) de Colombia. Biota Colomb 1:289-319

Anonymus (2002) Plan de Manejo Integral de los Humedales, Subregión de la Depresión Momposina y Cuenca del Río Sinú. Corporación Autónoma Regional del Sur del Bolívar (CVS), Cartagena, Colombia

Archila-M S (1993) Medio ambiente y arqueología de las tierras bajas del Caribe Colombiano. Boletín Museo del Oro 34-35. http://www.banrepcultural.org/blaavirtual/publicacionesbanrep/ bolmuseo/1993/endi3435/endi03a.htm 
Avise JC, Bowen BW, Lamb T, Meylan AB, Bermingham E (1992) Mitochondrial DNA evolution at a turtle's pace: evidence for low genetic variability and reduced microevolutionary rate in the Testudines. Mol Biol Evol 9:457-473

Beheregaray LB, Ciofi C, Caccone A, Gibbs JP, Powell JR (2003) Genetic divergence, phylogeography and conservation units of giant tortoises from Santa Cruz and Pinzón, Galápagos Islands. Conserv Genet 4:31-46

Bennett AM, Keeviland M, Litzgus JD (2010) Spatial ecology and population genetics of northern map turtles (Graptemys geographica) in fragmented and continuous habitats in Canada. Chelon Conserv Biol 9:185-195

Bohonak AJ (2002) IBD (isolation-by-distance): a program for analyses of isolation by distance. J Hered 93:153-154

Buitrago-Suárez UA, Burr BM (2007) Taxonomy of the catfish genus Pseudoplatystoma Bleeker (Siluriformes: Pimelodidae) with recognition of eight species. Zootaxa 1512:1-38

Clapperton CM (1993) Nature of environmental changes in South America at the Last Glacial Maximum. Palaeogeogr Palaeoclim Palaeoecol 101:189-208

Clement M, Posada D, Crandall KA (2000) TCS: a computer program to estimate gene genealogies. Mol Ecol 9:1657-1659

Corander J, Waldmann PM, Sillanpää J (2003) Bayesian analysis of genetic differentiation between populations. Genetics 163:367374

Cornuet JM, Luikart G (1996) Description and power analysis of two tests for detecting recent population bottlenecks from allele frequency data. Genetics 144:2001-2014

Echelle AA, Hackler JC, Lack JB, Ballard SR, Roman J, Fox SF, Leslie DM, Van Den Bussche RA (2010) Conservation genetics of the alligator snapping turtle: cytonuclear evidence of rangewide bottleneck effects and unusually pronounced geographic structure. Conserv Genet 11:1375-1387

Escalona T, Engstrom TN, Hernandez OE, Bock BC, Vogt RC, Valenzuela N (2009) Population genetics of the endangered South American freshwater turtle, Podocnemis unifilis, inferred from microsatellite DNA data. Conserv Genet 10:1683-1696

Evanno G, Regnaut S, Goudet J (2005) Detecting the number of clusters of individuals using the software STRUCTURE: a simulation study. Mol Ecol 14:2611-2620

Excoffier L, Smouse PE, Quattro JM (1992) Analysis of molecular variance inferred from metric distances among DNA haplotypes: application to human mitochondrial DNA restriction data. Genetics 131:479-491

Excoffier L, Laval G, Schneider S (2005) ARLEQUIN ver. 3.11: an integrated software package for population genetics data analysis. Evol Bioinf Online 1:47-50

Fantin C, Carvalho CF, Hrbek T, Sites JW, Monjelo LAS, AstolfiFilhos S, Farias IP (2007) Microsatellite DNA markers for Podocnemis unifilis, the endangered yellow-spotted Amazon River turtle. Mol Ecol Notes 7:1235-1238

Fetzner JW, Crandall KA (2003) Linear habitats and the nested clade analysis, an empirical evaluation of geographic versus river distances using an Ozark crayfish (Decapoda, Cambaridae). Evolution 57:2101-2118

FitzSimmons NN (1998) Single paternity of clutches and sperm storage in the promiscuous green turtle (Chelonia mydas). Mol Ecol 7:575-584

François O, Durand E (2010) Spatially explicit Bayesian clustering models in population genetics. Mol Ecol Resour 10:773-784

Fritz U, Havaš P (2007) Checklist of chelonians of the world. Vertebr Zool 57:149-368

Fu YX (1997) Statistical tests of neutrality of mutations against population growth, hitchhiking and background selection. Genetics 147:915-925
Fujii A, Forstner MRJ (2010) Genetic variation and population structure of the Texas tortoise, Gopherus berlandieri (Testudinidae), with implications for conservation. Chelon Conserv Biol 9:61-69

Gaffney ES, Tong H, Meylan PA (2006) Evolution of the side-necked turtles: the families Bothremydidae, Euraxemydidae, and Araripemydidae. Bull Am Mus Nat Hist 300:1-700

Gaffney ES, Meylan PA, Wood RC, Simons E, De Almeida Campos D (2011) Evolution of the side-necked turtles: the family Podocnemididae. Bull Am Mus Nat Hist 350:1-237

Gallego-García N (2004) Anotaciones sobre la historia natural de la tortuga de río Podocnemis lewyana en el río Sinú, Córdoba, Colombia. Undergraduate thesis, Universidad Nacional de Colombia, Bogotá, Colombia

Gallego-García N (2006) Programa de manejo y conservación de la tortuga de río Podocnemis lewyana. Informe final. Formulación e implementación de una estrategia para la conservación de la biota cordobesa. Convenio de cooperación Conservación Internacional y Corporación Autónoma Regional de los Valles del Sinú y San Jorge (CVS), Bogotá, Colombia

Gallego-García N, Castaño-Mora OV (2008) Ecology and status of the Magdalena River Turtle Podocnemis lewyana, a Colombian endemic. Chelon Conserv Biol 7:37-44

Galvis G, Mojica JI (2007) The Magdalena River fresh water fishes and fisheries. Aquat Ecosyst Health Manag 10:127-139

Galvis G, Mojica JI, Lozano C (1997) Peces del Catatumbo. Asociación Cravo Norte, Bogotá, Colombia

Garza C, Williamson EG (2001) Detection of reduction in population size using data from microsatellite loci. Mol Ecol 10:305-318

González-Porter GP, Hailer F, Flores-Villela O, García-Anleu R, Maldonado JE (2011) Patterns of genetic diversity in the critically endangered Central American river turtle: human influence since the Mayan age? Conserv Genet. doi: 10.1007/s10592-011-0225-x

Goudet J (2001) FSTAT, a program to estimate and test gene diversities and fixation indices (version 2.9.3). Department of Ecology and Evolution, University of Lausanne, Lausanne

Hall TA (1999) BIOEDIT: a user-friendly biological sequence alignment editor and analysis program for Windows 95/98/NT. Nucleic Acids Symp Ser 4:95-98

Hauswaldt JS, Glenn TC (2005) Population genetics of the diamondback terrapin (Malaclemys terrapin). Mol Ecol 14:723-732

Hubisz MJ, Falush D, Stephens M, Pritchard JK (2009) Inferring weak population structure with the assistance of sample group information. Mol Ecol Resour 9:1322-1332

IUCN (International Union for the Conservation of Nature and Natural Resources) (2010) IUCN Red List of Threatened Species (version 2010.1). http://www.iucnredlist.org

Johnson JA, Dunn PO, Bouzat JL (2007) Effects of recent population bottlenecks on reconstructing the demographic history of prairiechickens. Mol Ecol 16:2203-2222

Klemens MW (2000) Turtle conservation. Smithsonian Institution Press, Washington

Kuo CH, Janzen FJ (2004) Genetic effects of a persistent bottleneck on a natural population of ornate box turtles (Terrapene ornata). Conserv Genet 5:425-437

Latch EK, Dharmarajan G, Glaubitz JC, Rhodes OE (2006) Relative performance of Bayesian clustering software for inferring population substructure and individual assignment at low levels of population differentiation. Conserv Genet 7:295-302

Librado P, Rozas J (2009) DNASP v5: a software for comprehensive analysis of DNA polymorphism data. Bioinformatics 25: $1451-1452$

Livingstone DA, van der Hammen T (1978) Palaeogeography and palaeoclimatology. In: Tropical Forest Ecosystems: a state of knowledge. UNESCO, UNEO, FAO, Paris 
Luikart G, Cornuet JM (1998) Empirical evaluation of a test for identifying recently bottlenecked populations from allele frequency data. Conserv Biol 12:228-233

Luikart G, Allendorf FW, Cornuet JM, Sherwin WB (1998) Distortion of allele frequency distributions provides a test for recent population bottlenecks. J Hered 89:238-247

Maldonado-Ocampo JA, Vari RP, Usma JS (2008) Checklist of the freshwater fishes of Colombia. Biota Colomb 9:143-237

Mockford SW, McEachern L, Herman TB, Snyder M, Wright JM (2005) Population genetic structure of a disjunct population of Blanding's turtle (Emydoidea blandingii) in Nova Scotia, Canada. Biol Conserv 123:373-380

Moritz C (1994) Defining 'Evolutionarily Significant Units' for conservation. Trends Ecol Evol 9:373-375

Myers N, Mittermeier RA, Mittermeier CG, da Fonseca GAB, Kent J (2000) Biodiversity hotspots for conservation priorities. Nature 403:853-858

Páez VP, Restrepo A, Vargas-Ramírez M, Bock BC (2009) Podocnemis lewyana (Duméril 1852)—Magdalena River turtle. In: Rhodin AGJ, Pritchard PCH, van Dijk PP, Saumure RA, Buhlmann KA, Iverson JB, Mittermeier RA (eds) Conservation biology of freshwater turtles and tortoises: a compilation project of the IUCN/SSC Tortoise and Freshwater Turtle Specialist Group. Chelonian Research Monograph 5, Lunenburg, MA, USA, pp 024.1-024.6

Peakall R, Smouse PE (2005) GENALEX 6: genetic analysis in EXCEL. Population genetic software for teaching and research. Australian National University, Canberra

Pearse DE, Arndt AD, Valenzuela N, Miller BA, Cantarelli V, Sites JR (2006) Estimating population structure under nonequilibrium conditions in a conservation context: continent-wide population genetics of the giant Amazon River turtle, Podocnemis expansa (Chelonia; Podocnemididae). Mol Ecol 15:985-1006

Pedall I, Fritz U, Stuckas H, Valdeón A, Wink M (2011) Gene flow across secondary contact zones of the Emys orbicularis complex in the Western Mediterranean and evidence for extinction and re-introduction of pond turtles on Corsica and Sardinia (Testudines: Emydidae). J Zool Syst Evol Res 49:44-57

Piry S, Luikart G, Cornuet JM (1999) BOTTLENECK: a program for detecting recent effective population size reductions from allele frequency data. J Hered 90:502-503

Plazas C, Falchetti AM, van der Hammen T, Botero P (2005) Cambios Ambientales y Desarrollo Cultural en el Bajo Rio San Jorge. Boletín Museo del Oro 34-35. http://www.lablaa.org/ blaavirtual/publicacionesbanrep/bolmuseo/1988/bol20/bok4.htm

Pritchard JK, Stephens M, Donnelly P (2000) Inference of population structure using multilocus genotype data. Genetics 155:945-959

Rannala B, Mountain JL (1997) Detecting immigration by using multilocus genotypes. Proc Natl Acad Sci USA 94:9197-9201

Restrepo A, Páez VP, López C, Bock BC (2008) Distribution and status of Podocnemis lewyana in the Magdalena River Drainage of Colombia. Chelon Conserv Biol 7:45-51

Rice WR (1989) Analyzing tables of statistical tests. Evolution 43:223-225

Rioux Paquette S, Ferguson BH, Lapointe FJ, Louis EE (2009) Conservation genetics of the radiated tortoise (Astrochelys radiata) population from Andohahela National Park, southeast Madagascar, with a discussion on the conservation of this declining species. Chelon Conserv Biol 8:84-93

Rogers AR, Harpending H (1992) Population growth makes waves in the distribution of pairwise genetic differences. Mol Biol Evol 9:552-569

Rosenbaum PA, Robertson JM, Zamudio KR (2007) Unexpectedly low genetic divergences among populations of the threatened bog turtle (Glyptemys muhlenbergii). Conserv Genet 8:331-342
Ruiz-Carranza PM, Ardila-Robayo MC, Lynch JD (1996) Lista actualizada de la fauna Amphibia de Colombia. Rev Acad Colomb Cienc Exact Fís Nat 20:365-415

Salaman P, Donegan T, Caro D (2009) Checklist to the birds of Colombia 2009 [Listado de Aves de Colombia]. Conserv Colomb 8:1-89

Schneider S, Excoffier L (1999) Estimation of past demographic parameters from the distribution of pairwise differences when the mutation rates vary among sites: application to human mitochondrial DNA. Genetics 152:1079-1089

Seutin G, White BN, Boag PT (1991) Preservation of avian blood and tissue samples for DNA analyses. Can J Zool 69:82-90

Sites JW, FitzSimmons NN, Da Silva JN, Canterelli VH (1999) Conservation genetics of the giant Amazon River Turtle (Podocnemis expansa; Pelomedusidae): inferences from two classes of molecular markers. Chelon Conserv Biol 3:454-463

Spear SF, Peterson CR, Matocq MD, Storfer A (2006) Molecular evidence for historical and recent population size reductions of tiger salamanders (Ambystoma tigrinum) in Yellowstone National Park. Conserv Genet 7:605-611

Tajima F (1989) Statistical method for testing the neutral mutation hypothesis by DNA polymorphism. Genetics 123:585-595

Valenzuela N (2000) Multiple paternity in side-neck turtles Podocnemis expansa: evidence from microsatellite DNA data. Mol Ecol 9:99-105

van Oosterhout C, Hutchinson WF, Wills DPM, Shipley P (2004) MICRO-CHECKER: software for identifying and correcting genotyping errors in microsatellite data. Mol Ecol Notes 4:535-538

Vargas-Ramírez M (2007) Participatory research towards the conservation of the endangered-endemic river turtle Podocnemis lewyana in the upper Magdalena River, Colombia. Final report. http://fundacionbiodiversa.org/publicaciones.htm

Vargas-Ramírez M, Chiari Y, Castaño-Mora OV, Menken SBJ (2006) First genetic survey on the Magdalena's endemic fresh water turtle Podocnemis lewyana (Testudines, Podocnemididae) and its relation with human communities. Consequences for the species conservation. Final report. http://fundacionbiodiversa. org/publicaciones.htm

Vargas-Ramírez M, Chiari Y, Castaño-Mora OV, Menken SBJ (2007) Low genetic variability in the endangered Colombian endemic freshwater turtle Podocnemis lewyana (Testudines, Podocnemididae). Contrib Zool 76:1-7

Vargas-Ramírez M, Castaño-Mora OV, Fritz U (2008) Molecular phylogeny and divergence times of ancient South American and Malagasy river turtles (Testudines: Pleurodira: Podocnemididae). Org Divers Evol 8:388-398

Vargas-Ramírez M, Vargas-Ramírez JM, Lozano F (2009) Actions towards the conservation of the endangered-endemic fresh water turtle Podocnemis lewyana in the Upper Magdalena, River, Colombia. Final report. http://fundacionbiodiversa.org/ publicaciones.htm

Velo-Antón G, Cordero-Rivera A, García-París M (2008) Patterns of nuclear and mitochondrial DNA variation in Iberian populations of Emys orbicularis (Emydidae): conservation implications. Conserv Genet 9:1263-1274

Weber DS, Stewart BS, Lehman N (2004) Genetic consequences of a severe population bottleneck in the Guadalupe fur seal (Arctocephalus townsendi). J Hered 95:144-153

Wilson GA, Rannala B (2003) Bayesian inference of recent migration rates using multilocus genotypes. Genetics 163:1177-1191 